\title{
SSME at Manchester : Bringing People, Business and Technology Together
}

\author{
Linda Macaulay \\ University of Manchester \\ Manchester Business School, Manchester, U.K. \\ linda.macaulay@manchester.ac.uk
}

\author{
Liping Zhao \\ University of Manchester \\ School of Computer Science, Manchester, U.K. \\ liping.zhao@manchester.ac.uk
}

\begin{abstract}
IBM's Services, Sciences, Management, and Engineering (SSME) agenda proposes an emerging, multidisciplinary field that integrates a variety of technical and business fields under a general concept of "services". One important idea of the SSME agenda is innovative design in the $21^{\text {st }}$ century. This paper presents our SSME related activities around innovative business and curriculum design. Our business design focuses on IBM's Patterns for e-business whereas our curriculum design aims at providing students with new skills. These two activities are cross-fertilized owing to our collaborations with IBM through IBM Faculty Awards and the Strategic Partner Programme. Future research depends on further collaborations and on the development of a critical mass of SSME researchers. The paper concludes with a description of beginnings of a UK network of researchers brought together by the authors.
\end{abstract}

\section{INTRODUCTION}

IBM's Services, Sciences, Management, and Engineering (SSME) agenda [42] proposes an emerging, multidisciplinary field that integrates a variety of technical and business fields under a general concept of "services". One important idea of the SSME agenda is innovative design in the $21^{\text {st }}$ century. In his lecture at the University of Manchester, Wladawsky-Berger [43] put forward two cases of innovative design: business design and university curriculum design. The purpose of designing business is to identify its structure and components so that it can be integrated into a successful (and possibly global) enterprise; the purpose of designing university curriculum is to help students understand techniques for use in enabling such a business. Although the SSME framework is yet to be defined and developed, we believe that it builds on two foundations - systems theory and design theory-and three corner stones_-people, business and technology.

This paper presents our SSME related activities around innovative business and curriculum design. Our business design is a research activity based on IBM's Patterns for ebusiness whereas our curriculum design focuses on providing students with new skills. These two activities are cross-fertilized owing to our collaborations with IBM.

\section{CONTEXT}

IBM Faculty Awards

In 2004, Jonathan Adams, Distinguished Engineer at IBM, sponsored an IBM Global Faculty Award to the then two different universities, UMIST and VUM. The award was given to four academics, with Professor Linda Macaulay (Computation, UMIST) and Professor Brian Warboys (Computer Science, VUM) as Principal Investigators and Dr Peter Kawalek (Manchester Business School, UMIST) and Dr Liping Zhao (Computation, UMIST) as Coinvestigators.

The original aim of the award was to bring together researchers of different schools and disciplines to explore IBM Patterns for e-business [38] from three dimensions: research, teaching and business. The actual effect of this award, however, was far more significant. First, the award brought together researchers from two universities during a time of change and in this respect the award facilitated an understanding of and respect for differing perspectives. Second, the award stimulated the development of a new MSc programme —MSc e-business Technology-which would bring IBM's Patterns to the attention of a new generation of graduate students. Finally, the award led to a deeper interest in patterns. Such an interest would later become a common core for our pattern-oriented SSME research under the UoM-IBM Strategic Partner Programme.

Following the success of the first IBM Faculty Award, Adams sponsored Macaulay and Zhao with a second award in 2005, to encourage them to explore the role of Patterns for e-business in supporting the emerging Services Sciences discipline through research and teaching (http://www.research.ibm.com/ssme/workuniv.shtml). This award has further strengthened the relationship between Informatics and IBM and helped to develop a new collaboration with Paul Verschueren, Senior Consulting Architect at IBM and Chair of IBM Patterns Governance Board. More importantly, the award has connected the four authors of this paper through a shared interest in patterns, to explore the role of patterns in SSME for business design and to teach the students this design approach. 


\section{UoM-IBM Strategic Partner Programme}

The UoM-IBM Strategic Partner Programme was launched in January 2006 to explore areas of overlapping strategic importance to both organizations across research, teaching and recruitment. We are four of the 12 partners appointed in the first year. It is also worth mentioning that of the six partners from UoM, three partners are from Informatics: Professor Linda Macaulay, Professor Bob Wood and Dr Liping Zhao. Table 1 summarizes the UoM-IBM partner programme. Clearly, this programme accords with the SSME agenda.

\begin{tabular}{|c|l|}
\hline $\begin{array}{c}\text { Partners } \\
\text { (UoM/IBM) }\end{array}$ & \multicolumn{1}{c|}{ Programme } \\
\hline $\begin{array}{c}\text { Linda Macaulay/ } \\
\text { Jonathan Adams }\end{array}$ & $\begin{array}{l}\text { Extend IBM Patterns in the area of } \\
\text { Facilitated Collaboration and } \\
\text { explore the SSME agenda }\end{array}$ \\
\hline $\begin{array}{c}\text { Liping Zhao / } \\
\text { Paul Verschueren }\end{array}$ & $\begin{array}{l}\text { Explore the role of patterns in the } \\
\text { SSME agenda and develop } \\
\text { techniques to support patterns }\end{array}$ \\
\hline $\begin{array}{c}\text { Bob Wood / } \\
\text { Henry Law }\end{array}$ & $\begin{array}{l}\text { Explore the role of the IT Architect } \\
\text { and its future impact on teaching } \\
\text { and research }\end{array}$ \\
\hline $\begin{array}{l}\text { Kung-Kiu Lau / } \\
\text { Trevor Hopkins }\end{array}$ & $\begin{array}{l}\text { Construct large software } \\
\text { applications using components }\end{array}$ \\
\hline $\begin{array}{c}\text { Barbara Jones / } \\
\text { Angelo Failla }\end{array}$ & $\begin{array}{l}\text { Focus on developing new ICT skills } \\
\text { in organizations that are undergoing } \\
\text { rapid change and how employees } \\
\text { apply that knowledge as new } \\
\text { challenges arise }\end{array}$ \\
\hline $\begin{array}{l}\text { Alex May / } \\
\text { Andy Heys }\end{array}$ & \begin{tabular}{l} 
Develop bio-health informatics \\
\hline
\end{tabular}
\end{tabular}

Table 1. The UoM-IBM Strategic Partner Programme.

\section{BUSINESS DESIGN USING PATTERNS}

IBM is a leading business designer who has developed a large number of methods and technologies that support business design. Among these technologies are Component Business Modeling (CBM), Service Oriented Modeling and Architecture (SOMA), and Patterns for e-business (P4eb). CBM and SOMA are used to identify and describe the business processes whereas P4eb map these processes onto the architectural components of the software systems.

P4eb was identified from thousands of successful IBM application development projects by Adams and his colleagues at IBM [38]. These patterns give businesses a set of proven, reusable architectural components that can guide the design, development, implementation and extension of e-business applications.
P4eb are organized into a hierarchy. At the top level are four Business Patterns: Self-Service, Collaboration, Information Aggregation and Extended Enterprise. These four patterns represent four distinctive types of business interaction. Specifically, Self-Service describes the interaction between users and businesses; Collaboration captures the interaction between users; Information Aggregation represents the interaction between users and data; Extended Enterprise expresses the interaction between businesses. Each Business Pattern is specialized into a set of Application Patterns, which, in turn, are further divided into Runtime Patterns. An Application Pattern describes a logical design of the system whereas a Runtime Pattern suggests an implementation plan (product mapping) for the system. Business Patterns are supported by other patterns such as Integration Patterns, which are Access Integration, for the front-end system integration, and Application Integration, for the back-end system integration.

We are conducting research to enhance $\mathrm{P} 4 \mathrm{eb}$ in the following areas.

- Extend the Collaboration pattern family with new patterns, such as facilitated collaboration patterns.

- Extend P4eb with business logic patterns. P4eb are the solutions to the architectural design of the business systems, but not the solutions for the business logic design of the applications. Although the business logic solutions can be provided by other approaches, such as CBM and SOMA, we are exploring a pattern-oriented approach to designing business logic and components.

- Develop methods and tools for pattern organization and selection. Although the top level of P4eb only has four Business Patterns, the number of patterns grows exponentially at the lower-levels. For example, there are about 100 Application Patterns and hundreds of Runtime Patterns. Methods and tools that support effective pattern organization and selection are therefore urgently needed.

We propose to use patterns to support business design in relation to SSME agenda for the following related reasons.

- Patterns are a universal design concept. Either in art or engineering, patterns represent geometric arrangements of parts that can be used over again. For example, patterns are used to design dresses, carpets, wallpapers, airplanes, buildings [39], and software [41], to name only a few. As a design concept, patterns preserve tried, tested experience and best practice. Patterns mean goodness and fit.

- Patterns are a recurring phenomenon. Thus we can speak of weather patterns, symptoms, DNA sequences, communication and control patterns, and behavioral patterns.

- Patterns are relationships between parts and wholes in natural as well as artificial systems [40]. Thus patterns capture fundamental organizing principles and structures 
in systems, such as the structures of molecules, society, and computer systems.

In addition, patterns give us an effective, common language for communication, so that we can say: "Let's use SelfService for this business application", or "This is an Extended Enterprise problem.” Patterns, as in the form of IBM P4eb, are organized as a hierarchy. By using such a hierarchy of patterns, we can decompose a problem space. For example, the Self-Service pattern can be decomposed into different Application Patterns which are then divided into different Runtime Patterns and so on. In this respect, patterns help us to reduce the design complexity.

\section{SSME COURSE DESIGN}

According to Wladawsky-Berger [43], UoM is among 11 selected universities who have developed SSME courses. In particular, UoM has introduced the following Master of Science MSc e-business Technology

\section{MSc e-business Technology}

Today nearly every business involves some technology support. The Internet has become the gateway to most businesses. E-business is therefore a norm for business. This MSc programme equips the students with the skills in analysis, design and development of e-business application systems. Possible career paths for the students upon successful completion of the programme include e-business analysis and design, solutions development, and web service development and web site design.

Among other taught courses offered in this programme are e-business and Patterns for e-business Applications, which directly address the SSME agenda. The e-business course teaches the students the following components: (1) ebusiness infrastructure and strategy; (2) supply chain management and e-procurement; (3) customer relationship management; (4) e-marketing; (5) collaborative commerce; (6) case studies. The Patterns for e-business Applications course teaches the students the following components: (1) relationships between business requirements and e-business application architectures; (2) relationships between business drivers and technologies; (3) IBM's Patterns for e-business as solutions for e-business application system design; (4) relationships between business processes and IBM Patterns; (5) real world case studies.

These two courses are developed as a result of the two IBM Faculty Awards described above and team-taught by the four authors: Macaulay is the academic instructor for the ebusiness course with Adams as the industrial instructor; Zhao is the academic instructor for Patterns for e-business course with Verschueren as the industrial instructor. The courses have attracted 80 students from the UK and abroad, and proved to be very successful and popular among the students. Students' performance and feedback have indicated that patterns provide an effective pedagogical tool to e-business application design and help the students to gain a better understanding of the relationship between business needs and technical solutions.

\section{UK Network of Researchers in Services Sciences}

In order to bring together researchers from a range of disciplines across the UK to develop a shared understanding and research agenda of SSME, Macaulay and Zhao are driving a proposal for the development of a UK Network of Researchers in Services Sciences. Currently, 14 leading academics from different UK universities have joined us to serve as the founding members of the proposed network; three leading companies, IBM, BT and HP, have agreed to support this network. A number of grand challenges have been identified for the SSME agenda. For example, the NESSI (Networked European Software and Services Initiative) Working Group states that the SSME challenge is "to establish attainable expectations that services systems will function according to their specifications, at predicted costs, throughout their intended lifetimes 16.” Associated with this challenge are the technical difficulties in developing services systems, due to their scale, integration, environment, communication problems. Other challenges include the semantic representation of people, technologies and organizations, as well as their capabilities, goals, rights and values, and the integration of information and knowledge from different artefacts and organizations [16].

This proposal, however, recognizes that dealing with service complexity is the ultimate challenge of the SSME agenda based on the following facts:

- Many of today's services require the cooperation of people, business and technologies in many different disciplines. Delivering and innovating services will involve understanding people's behaviour, the way they conduct businesses and the role of technologies in businesses.

- Services have become increasingly complex and dynamic owing to the cross-industry, cross-market, and cross-country business activities and collaborations.

- The Internet and IT technology have made it possible for companies to work together intensively and in new ways, to form complex supply chains and service networks. Technologies have become a crucial part of services and service innovation. It can be argued that technologies are the defining characteristic of modern services and the challenge of SSME is the complexity of designing and innovating services around technologies.

To address the above challenge, the objectives of SSMEnetUK are to facilitate the collaboration of research and education in service design and service innovation within and beyond EPSRC support. The founding members' expertise can be mapped onto this scope as follows. 
1) Service Design. The purpose of designing services is to identify their structure and components so that they can be changed, managed and controlled [36,37]. Yet, service design is a challenge because today's services interact and integrate with other systems, including people, products, businesses, economics, social systems, political systems, and IT systems. Service design is therefore a highly complex activity. The proposed network will build on the strength and expertise of its founding members to identify the need for design methodologies, techniques and architectures for services. In particular, Bennett and Gold $[23,9]$ are interested in service-oriented architecture whereas Zhao and Sampiao [7,25,26,27] are looking into using the web service technology to support e-services; Hollins [10] is concerned with design standards and regulations, while Macaulay and Zhao [36,37] advocate the pattern approach to business design. Van Moorsel is currently working on self-managing computing systems and services [32,33,34] so that services can be more efficiently and effectively operated, and better utilized by people and businesses. These efforts will be combined to address the service design challenge within the proposed network.

2) Service Innovation. Service innovation has become one of the success criteria in the modern economy $[14,18]$. Since services depend critically on people working together and with technology to provide value for others, new skills are required for integrating business, people and technology. Skill innovation will therefore go hand in hand with service innovation. Two founding members of this proposal, Miles and Jones $[20,12,13,14,15]$ are experts in service innovation and skills. They stress the diversity of service activities and of related innovation processes, and have been characterizing different types of knowledge base and network organization. Fowler [31] is interested in Human Interaction with Services while Sako [23] takes a social science perspective on services. These efforts will be combined to address the service innovation challenge within the proposed network.

\section{CONCLUSION}

This paper has reported our SSME related research and teaching activities. Our research activity focuses on using patterns for business design whereas our teaching activity concentrates on designing new services courses for MSc students. The paper has also outlined our collaborations with IBM and highlighted the need to develop a critical mass of researchers to allow the SSME research agenda to flourish.

\section{REFERENCES}

1.B. Andersen, J. Howells, R. Hull, I. Miles, and J Roberts (eds), Knowledge and Innovation in the New Service Economy, Cheltenham, Elgar, 2000.

2.K.H. Bennett, M. Munro, N.E. Gold, P.J. Layzell, D. Budgen, P. Brereton, "An Architectural Model for Service-Based Software with Ultra Rapid Evolution”, Proceedings of the IEEE
International Conference on Software Maintenance (ICSM) 2001, 6-10 November 2001, Florence, Italy, pp. 292-300.

3.K.H. Bennett, N.E. Gold, P.J. Layzell, F. Zhu, O.P. Brereton, D. Budgen, J. Keane, I. Kotsiopoulos, M. Turner, J. Xu, O. Almilaji, J.C. Chen, A. Owrak, "A Broker Architecture for Integrating Data Using a Web Services Environment," Proceedings of the First International Conference on ServiceOriented Computing (IC-SOC), Trento, Italy, 15-19 December 2003, pp. 409-422.

4.M. Boden and I. Miles (eds), Services, Innovation and the Knowledge Economy, London, Continuum ISBN 0-82644592-2 (hdbck) 0-8264-4953-0 (pprbck)

5.H. Chesbough and J. Spohrer, "A Research Manifesto for Services Science," Communications of the ACM, Vol. 49, No. 7, 35-40, July 2006.

6.P. Cunningham, C. Grant-Pearce, L. Green, I. Miles, E Uyarra, "In Sickness, in Health and in Innocation: NHS DIRECT - a health sector innovation study” Administration vol. 53 no 3 pp42-65, 2005.

7.L. Eleyan, L. Mikhailov and L. Zhao, "Quality-of-Services in Web Services Architecture,” Ingénierie des Systèmes d'Information, Special Issue on Information Systems Quality, vol. 9, no. 5-6, pp. 185-203, 2004.

8.J. Gershuny and I. Miles, The New Service Economy, London: Frances Pinter 1983, (Japanese translation published Tokyo, 1987)

9.N. Gold, "SOSoRNet: Service-Oriented Software Research Network," Case for Support, Proposal for EPSRC Grant.

10.B. Holins, “About: Service Design”, available at www.designcouncil.org.uk. 2006.

11.P. Horn, "The New Discipline of Services Science,” Viewpoint, BusinessWeek online, January $21^{\text {st }} 2005$.

12.B. Jones and A.R. Miller, Innovation Diffusion in the New Economy: the Tacit Component, Routledge Advances in Management \& Business Studies, 2006.

13.B. Jones, J. Cullen and A.R. Miller, "European Movement Towards a Competency-based Skills Taxonomy and Personal Skills Profile," Management of Technology, T Khalil, L A Lefebre and R M Mason (eds), Pergamon - Elsevier Science, 2001.

14.B. Jones and K. Hadjivassilou, "New Methods of Skill Definition and Accreditation", in Identification, Evaluation and Recognition of Non-formal Learning: Agora V, E Guggenheim (ed),CEDEFOP Panorama Series, Luxembourg, 2002.

15.B. Jones, A. Failla and A.R. Miller, "Tacit knowledge in rapidly evolving organisational environments," International Journal of Technology and Human Interaction, (forthcoming Autumn 2006).

16.M. Lyons, D. Pym, R. Taylor, J. Sairamesh, C. Schulze, L. Svobodova, "NESSI Working Group: Services Sciences \& Systems Engineering," White paper, 2006.

17.C. Martinez and I. Miles, "Inside the software firm: coproduction of knowledge and KISA in the innovation process"International Journal of Services Technology and Management vol. 7 no 2 pp115-125, 2006.

18.S Metcalfe and I. Miles (eds), Innovation Systems in the Service Economy, Dordrecht: Kluwer, 2000.

19.B. Monahan, D, Pym, R. Taylor, C. Tofts, M. Yearworth, “Engineering the Polymath,” Position paper. The 2006 National Academy of Sciences Meeting on Innovation in Systems and Services Education Workshop, Washington, April $18^{\text {th }} 2006$.

20.I. Miles,"Knowledge Intensive Business Services: Prospects and policies" Foresight vol. 7 no 6 pp39-63, Note: this won the 
“"Highly Commended Award” for 2006 from the Emerald Literati Network.

21.D, Pym, R. Taylor, C. Tofts, "Systems and Services Sciences: A Rationale and A Research Agenda,” Position paper, HP, May 16, 2006.

22.A. Salter and B.S. Tether, "Innovation in Services," Background paper for Advanced Institute of Management (AIM) Research's Grand Challenge on Service Science,” 7 April 2006.

23.M. Sako, “Grand Challenges in Services,” GCS Workshop Presentation, Said Business School. Oxford, 19 May 2006.

24.T. Sakao and Y. Shimomura. "A Method and a Computerized Tool for Service Design,” Design 2004 Conf. Cavtat 17-20 May, pp 497- 502, 2004.

25.P. Sampaio and H. Yong, "Unbundling and delivering CRM applications as e-Services: A case study in customer segmentation," to appear in the International Journal of Services Technology and Management, Special Issue on e-Services Delivery, 2006.

26.P. Sampiao, "Business process design and implementation for customer segmentation e-services”, Proceedings of the IEEE International Conference on e-Technology, e-Commerce and eService, Hong Kong. April 2005, pp 228-234.

27.P. Sampaio and H. Yong, "Unbundling and Deploying CRM Applications as e-Services," Proceedings of $5^{\text {th }}$ Workshop in Enterprise Modelling and Information Systems Architectures, Current Research Topics and Future Perspectives, Lecture Notes in Informatics, Klagenfurt, Carinthia, Austria, Oct 24-25, 2005, issue 75, pp 123-136.

28.A. Sheth, K. Verma and K. Gomadam, "Semantics to Energize the Full Services Spectrum," Communications of the ACM, Vol. 49, No. 7, 52-64, July 2006.

29.J. Spohrer and D. Riecken (guest editor), Special Section on Services Science, Communications of the ACM, Vol. 49, No. 7, 31-90, July 2006.

30.G. Thomas and I. Miles, Telematics in Transition: the emergence of new interactive services, Harlow: Longmans, 1989.

31.J. Van Helvert and C.J.H. Fowler, "Scenarios for Innovation (SUNA,”. In I. Alexander \& N Maiden (eds) Scenarios and Use Cases Stories through the System Life-Cycle. Wiley, 2004.

32.A. van Moorsel, "Grid, Management and Self-Management," The Computer Journal, British Computer Society, Oxford University Press, UK, vol. 48, no. 3, pp. 325-332, 2005.
33.A. van Moorsel, "Ten-Step Survival Guide for the Emerging Business Web," Invited paper accompanying keynote, in Lecture Notes in Computer Science, International Workshop on Web Services, E-Business, and the Semantic Web, pp. 1-11, Springer, LNCS 2512, 2002.

34.A. van Moorsel. "Metrics for the Internet Age: Quality of Experience and Quality of Business," Hewlett Packard Laboratories, Technical Report HPL-2001-179, 2001.

35.I.Wladawsky-Berger, "Innovation in the 21 Century," The Irving Wladawsky-Berger Lecture at the University of Manchester, 21 March, 2006. Available at www.cs.manchester.ac.uk

36.L. Zhao, L. Macaulay, P. Verschueren, and J. Adams, "Services Science at Manchester: Bringing People, Business and Technology Together," Position paper, IBM Summit on Service Sciences, Management and Engineering: Education for the 21st Century, New York, Oct, 5-7, 2006. Available at http://www.almaden.ibm.com/asr/summit/papers.shtml.

37.L. Zhao, N. Mehandjiev and L. Macaulay, "Agent roles and patterns for supporting dynamic behavior of web service applications," Workshop on Web Services and Agent-Based Engineering (WSABE), International Joint Conference on Autonomous Agents and Multi-Agent Systems (AAMAS'04) New York, 2004.

38. J. Adams, S. Koushik, G. Vasudeva, and G. Galambos, Patterns for e-business: A Strategy for Reuse, IBM Press, 2001. Pattern descriptions also available at www.ibm.com/developerWorks/patterns

39. C. Alexander, The Timeless Way of Building, New York: Oxford University Press, 1979.

40. F. Capra, The Web of Life, Flamingo. 1997.

41. E. Gamma, R. Helm, R. Johson, and J. Vlissides, Design Patterns. Addison-Wesley, Reading, MA, 1996.

42. P. Horn, "The New Discipline of Services Science," Viewpoint, BusinessWeek online, January $21^{\text {st }} 2005$.

43. I.Wladawsky-Berger, "Innovation in the 21 Century,” The Irving Wladawsky-Berger Lecture at the University of Manchester, 21 March, 2006. Available at www.cs.manchester.ac.uk 